Rev. Int. Contam. Ambie. 36 (4) 977-984, 2020

https://doi.org/10.20937/RICA.53562

\title{
CONCENTRATION OF TRACE METALS IN SOME MAJOR EDIBLE OILS OF RIYADH
}

\author{
Concentraciones de elementos traza en algunos aceites comestibles de Riad
}

$$
\text { Ibrahim MOHAMMED ALRAJHI }{ }^{1} \text { and Hajo IDRISS }{ }^{2,3 *}
$$

${ }^{1}$ Prince Sultan Military Medical City, Po. Box 7897 Riyadh 11159, Kingdom of Saudi Arabia.

${ }^{2}$ Deanship of Scientific Research, Imam Mohammad Ibn Saud Islamic University), Riyadh, Saudi Arabia

${ }^{3}$ Sudan Atomic Energy Commission.

*Corresponding author: hjoidriss@gmail.com

(Received: March, 2019; accepted: March, 2020)

Key words: vegetable edible oil, heavy metals, essential elements, ICP-OES, KSA.

\begin{abstract}
Chemical elements play major roles in various metabolic processes in the human body. Moreover, some of these elements are toxic if consumed in excessive quantities. In this study, a total of 11 elements $\left(\mathrm{Mn}^{+2}, \mathrm{Fe}^{+2}, \mathrm{Cu}^{+2}, \mathrm{Cr}^{+3}, \mathrm{Zn}^{+2}, \mathrm{Ni}^{+2}, \mathrm{Se}, \mathrm{Pb}^{+2}, \mathrm{As}^{+3}\right.$, and $\mathrm{Al}^{+3}$ ) were studied in edible vegetable oil samples by using an inductively coupled plasma-optical emission spectrometer. The concentration of the metals was found to be in trace level lower than the maximum allowable concentration limit set by the World Health Organization as well as the recommended daily intake of metals. Pearson correlation coefficients showed strong correlations between $\mathrm{Cr}$ and $\mathrm{Fe}(0.998), \mathrm{Cr}$ and $\mathrm{Mn}$ (0.994), Cr and Ni (0.985), Fe and Mn (0.994), Fe and Ni (0.985), Mn and Ni (0.978), and $\mathrm{As}$ and $\mathrm{Se}(0.997)$. It can be concluded that the edible vegetable oil samples were free of any chemical element contamination.
\end{abstract}

Palabras clave: aceite vegetal comestible, metales pesados, elementos esenciales, ICP-OES, RAS.

\section{RESUMEN}

Los elementos químicos desempeñan un papel importante en varios procesos metabólicos en el cuerpo humano. Además, algunos de estos elementos son tóxicos si se consumen en cantidades excesivas. En esta investigación se estudió un total de 11 elementos (Mn, $\mathrm{Fe}, \mathrm{Cu}, \mathrm{Cr}, \mathrm{Zn}, \mathrm{Ni}, \mathrm{Al}, \mathrm{Pb}, \mathrm{As}$, Se y Al) en muestras de aceite vegetal comestible mediante el uso de un espectrómetro de emisión óptica de plasma acoplado inductivamente. Se encontró que la concentración de los metales estaba en un nivel de traza inferior al límite de concentración máximo establecido por la Organización Mundial de la Salud, así como de la ingesta diaria recomendada de esos metales. Los coeficientes de correlación de Pearson mostraron una fuerte correlación entre $\mathrm{Cr}$ y $\mathrm{Fe}$ (0.998), Cr y Mn (0.994), Cr y Ni (0.985), Fe y Mn (0.994), Fe y Ni (0.985), Mn y Ni (0.978) y As y Se (0.997). Se puede concluir que las muestras de aceite vegetal comestible estaban libres de contaminación por elementos químicos. 


\section{INTRODUCTION}

Edible oils are extremely important food for all people around the world. They are extracted from plants (e.g., soybean, canola, and chili); seeds (e.g., corn, sesame and sunflower); nuts (e.g., walnut and macadamia); and fruits (e.g., watermelon palm, olive, and coconut). Relying on oil sort, they are widely used in cooking (bread preparation and frying food) and for non-cooking products such as salad, pastry, and appetizers. In addition, edible oils are used to produce nonfood products such as cosmetics, pharmaceutical, and as biofuels.

The human body utilizes oils and fats in the diet for important purposes, as energy and vitamins suppliers, and also as essential elements in metabolic reactions in the human body (Dugo et al. 2004). Human beings, plants and animals rely on major metals such as $\mathrm{Ca}, \mathrm{Mg}, \mathrm{Fe}, \mathrm{Cu}, \mathrm{Zn}$ and $\mathrm{Mn}$ for growth and development, though some metals are benefic and others can be toxic, even in low quantity, and thus pose health risks to humans and animals (Sanches-Filho et al. 2017). While the effect of chronic exposure to small amounts of some metals seems to be well understood, several incidents show the seriousness of high levels of exposure to some noxious metals, particularly $\mathrm{Cd}, \mathrm{Cr}^{+3}$, and $\mathrm{Pb}$ (Garrido et al. 1994, Buldini et al. 1997, Rajeshkumar et al. 2017). The quality of edible oils is directly linked to the concentration of many trace metals. Concentrations of $\mathrm{Fe}, \mathrm{Cu}, \mathrm{Co}, \mathrm{Ni}$ and $\mathrm{Mn}$ are known to increase the rate of oil oxidation, while elements like $\mathrm{As}, \mathrm{Cr}, \mathrm{Cd}$, and $\mathrm{Pb}$ are significant on account of their toxicity and metabolic role (Manjusha, et al. 2019).

The presence of metals in vegetable edible oils relies on many factors. They may come from the soil, environment, and genetic structure of the plant, as well as fertilizers and pesticides introduced during the production process or by contamination from the metal processing equipment or shipping containers (Cindiric et al. 2007, Jamali et al. 2008). If toxic metals are consumed the risk of a particular population may increase, so it is essential to determine the concentration of these metals (Sobhan 2016). Many studies have been recently carried out on the determination of heavy metals in edible oils all over the world (Cindiric et al. 2007, Mendil et al. 2009, Bakkali et al. 2012, Savio et al. 2014, Barreto et al. 2018, Manjusha et al. 2019, Karasakal 2020). Food contamination by heavy metals has become a reality and constitute a challenge for many countries (Karimi et al. 2015). The purpose of this work is to determine the concentrations of essential and potentially toxic metals in edible vegetable oils sold in Riyadh markets.

\section{MATERIALS AND METHODS}

\section{Study area}

The study area was Riyadh, one of the biggest cities and capital of the Kingdom of Saudi Arabia, with an area of about $1554 \mathrm{~km}^{2}$ and an estimated population of 7231447 . It is located centrally in the Najd region and lies between latitude $34^{\circ}-38^{\circ} \mathrm{N}$ and longitude $43^{\circ}-46^{\circ} \mathrm{E}$, as shown in figure 1 .

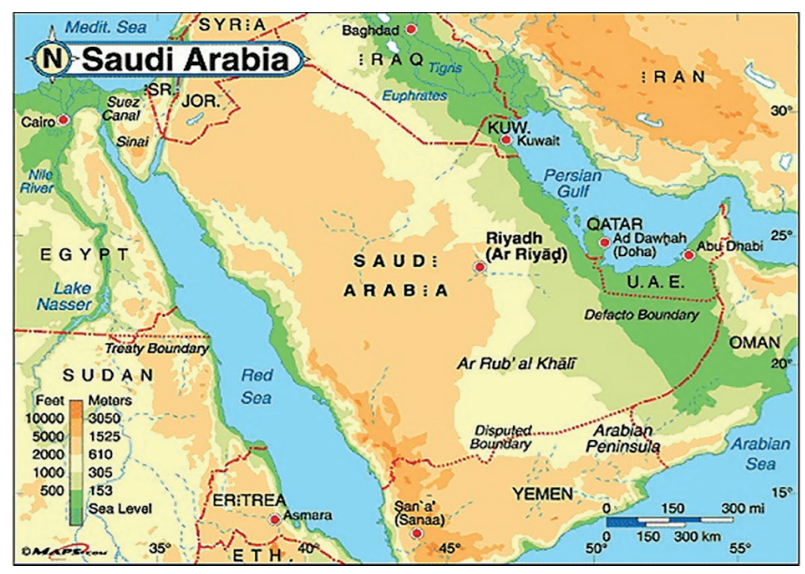

Fig. 1. Map of Saudi Arabia showing Riyadh city.

\section{Sample preparation}

A total of 54 edible vegetable oil samples (soybean, palm and olive) were collected from the supermarkets around the city of Riyadh and transported to the environmental research laboratory at Imam Mahammad Ibn Saud University for elemental analysis. Ten milliliters of high purity $\mathrm{HNO}_{3} 65 \%$ and $2 \mathrm{ml}$ of $\mathrm{H}_{2} \mathrm{O}_{2} 30 \%$ were added to the beaker containing $2 \mathrm{~g}$ of dry samples and were placed in the fume cupboard for two days for digestion. The mixture was then digested at $80{ }^{\circ} \mathrm{C}$ till a transparent solution was achieved. After cooling, the digested samples were filtered using Buchner funnels and the filtrate was diluted to $45 \mathrm{~mL}$ with distilled water. Then the samples were analyzed using inductively coupled plasma atomic emission spectroscopy (ICP-AES). The analyzed elements were $\mathrm{Cd}, \mathrm{Cr}, \mathrm{Cu}, \mathrm{Fe}, \mathrm{Mn}, \mathrm{Ni}$, $\mathrm{Pb}, \mathrm{Zn}, \mathrm{As}$, Se and Al (al-Rajhi 2014). 


\section{Spectrometric analysis}

The measurements were performed using a Genesis ICP optical emission spectrometer (Spectro Analytical Instruments, Kleve, Germany) with axial plasma observation. The instrument includes a Paschen-Runge mount spectrometer, constructed employing the optimized Rowland Circle Alignment (ORCA) technique. It consists of two hollow section cast shells, designed for direct thermal stabilization and small volume. Fifteen pre-aligned linear coupled-charge devices (CCDs) were installed outside the optics body, which allows fast, simultaneous spectrum capture of the wavelength range between 175 and $777 \mathrm{~nm}$. For UV access $<200 \mathrm{~nm}$, the optical system was purged with argon at a rate of $0.5 \mathrm{~L} / \mathrm{min}$ during normal operation. Intelligent calibration logic (ICAL) was used to normalize the wavelength and the intensity of the optical system to a reference optic (optic master). The stability of the forward power in the case of rapidly changing sample loads was achieved by using an air-cooled ICP-generator based on a free running $27.12 \mathrm{MHz}$ system. All ICP operating parameters were software controlled. The ICP-OES instrument was initialized and allowed to achieve thermal equilibrium over $30 \mathrm{~min}$. ICP-OES determinations of elements concentration were performed using the emission lines 228.802, 267.716, 324.752, 238.204, 285.213, 259.372, 231.604, 220.353, 213.857, 189.641, 196.090, and $384.401 \lambda(\mathrm{nm})$ for the elements $\mathrm{Cd}$, $\mathrm{Cr}, \mathrm{Cu}, \mathrm{Fe}, \mathrm{Mg}, \mathrm{Mn}, \mathrm{Ni}, \mathrm{Pb}, \mathrm{Zn}, \mathrm{As}, \mathrm{Se}$, and $\mathrm{Al}$, respectively (al-Rajhi 2014).

\section{Quality control}

All the standard stock solutions of heavy metals were certified reference materials purchased from Agilent Technologies (USA). $\mathrm{HNO}_{3}$ and $\mathrm{H}_{2} \mathrm{O}_{2}$ were heavy metal analytical grade purchased from Wako Chemical (USA). Reagent water, toluene and acetone were of analytical reagent grade purchased from J.T. Baker (USA). Adequate quality control method and vigilance were carried out in order to get reliable results. Throughout the experiments, all glassware and equipment were cautiously washed beginning with acetone followed by $5 \% \mathrm{HNO}_{3}$ and ending with repeated rinsing distilled water to prevent contamination. Reagent blank determinations were used to correct the readings. The lower detection limit values of the elements were found in this study to be 0.001 $\mathrm{mg} / \mathrm{kg}$ for $\mathrm{Cr}, 0.001 \mathrm{mg} / \mathrm{kg}$ for $\mathrm{Cu}, 0.0001 \mathrm{mg} / \mathrm{kg}$ for $\mathrm{Zn}, 0.002 \mathrm{mg} / \mathrm{kg}$ for Fe, $0.003 \mathrm{mg} / \mathrm{kg}$ for $\mathrm{Mn}, 0.0001$ $\mathrm{mg} / \mathrm{kg}$ for $\mathrm{Cd}, 0.001 \mathrm{mg} / \mathrm{kg}$ for Al, $0.001 \mathrm{mg} / \mathrm{kg}$ for $\mathrm{Ni}, 0.01 \mathrm{mg} / \mathrm{kg}$ for $\mathrm{Se}, 0.004$ for $\mathrm{Pb}$ and $0.01 \mathrm{mg} / \mathrm{kg}$ for As. The recovery values were nearly quantitative (95\%) for digestion method. The relative standard deviations were less than $10 \%$ for all investigated elements. Multi-element solution standards obtained from Agilent Technology were used to calibrate and calculate sample results.

\section{RESULTS AND DISCUSSION}

The determination of the elemental concentration in edible vegetable oil is vital, since several elements play major roles in various metabolic processes in the human body. Moreover, some of these elements are toxic if consumed in excessive quantities. In this study, 11 elements (Mn, Fe, Cu, Cr, Zn, Ni, Al, Pb, As, $\mathrm{Cd}, \mathrm{Se}$, and $\mathrm{Al}$ ) in edible vegetable oil samples were studied using ICP-OES, as shown in table I and Fig. 2.

\section{Nickel}

Ni concentrations varied from 0.002 to $1.215 \mathrm{mg} / \mathrm{kg}$ with an average value of $0.065 \mathrm{mg} / \mathrm{kg}$. The concentration of Ni control samples was $0.01 \mathrm{mg} / \mathrm{kg}$. Upon comparing the average values of $\mathrm{Ni}$ in the obtained results with control and global data, it was found that the obtained values were far below the reported average values from Pakistan, Turkey and Spain (Cindiric et al. 2007, Lorent et al. 2011). The nickel average daily intake $(0.023011 \mathrm{mg} / \mathrm{kg})$ was found to be lower than the maximum allowable concentration limit set by the World Health Organization (100-300 $\mathrm{mg} / \mathrm{kg}$ ) (WHO 1995). Trace amounts of Ni may be beneficial as activators of some enzyme systems, but its toxicity at higher levels is more prominent (Ameen et al. 2019).

\section{Copper}

Cu concentrations ranged from $0.001-0.081 \mathrm{mg} / \mathrm{kg}$ with an average value of $0.011 \mathrm{mg} / \mathrm{kg}$. The concentration of control samples was $0.0001 \mathrm{mg} / \mathrm{kg}$. The $\mathrm{Cu}$ concentration range was lower than that reported in similar data $(0.02-0.33 \mathrm{mg} / \mathrm{kg})$ (Garrido et al. 1994), 12.71-50.5 mg/kg (Buldini et al. 1997), $0.15-1.5 \mathrm{mg} / \mathrm{kg}$ (Zeiner et al. 2005), 0.0184-0.2870 $\mathrm{mg} / \mathrm{kg}, 0.05-0.71 \mathrm{mg} / \mathrm{kg}$ (Mendil et al. 2009), and $0-130 \mathrm{mg} / \mathrm{kg}$ (Llorent et al. 2011). The $\mathrm{Cu}$ average daily intake $(0.004 \mathrm{mg} / \mathrm{kg})$ was found to be lower than the maximum allowable concentration limit set by the Food and Agriculture Organization of the United Nations and WHO (3 mg/kg) (FAO-WHO 1999). $\mathrm{Cu}$ has numerous functions in the human body, but excessive intake of this element has been reported to be toxic. 
TABLE I. AVERAGE CONCENTRATIONS* OF Cd, Cr, Cu, Fe, Mn, Ni, Pb, Zn, As, Se AND Al IN EDIBLE VEGETABLE OIL.

\begin{tabular}{|c|c|c|c|c|c|c|c|c|c|c|c|}
\hline No. & $\mathrm{Cd}$ & $\mathrm{Cr}$ & $\mathrm{Cu}$ & $\mathrm{Fe}$ & $\mathrm{Mn}$ & $\mathrm{Ni}$ & $\mathrm{Zn}$ & $\mathrm{Al}$ & $\mathrm{Pb}$ & As & $\mathrm{Se}$ \\
\hline 1 & 0.001 & 0.004 & 0.004 & 0.061 & LDL & 0.038 & 0.013 & 0.179 & 0.006 & 0.28 & 0.278 \\
\hline 2 & LDL & 0.009 & 0.005 & 0.048 & 0.001 & 0.042 & 0.004 & 0.014 & 0.004 & 0.099 & 0.102 \\
\hline 3 & 0.001 & 0.014 & 0.005 & 0.305 & 0.001 & 0.018 & 0.013 & 0.295 & 0.004 & 0.309 & 0.284 \\
\hline 4 & 0 & 0.004 & 0.007 & 0.056 & 0.001 & 0.026 & 0.048 & 0.111 & 0.004 & 0.18 & 0.183 \\
\hline 5 & 0.001 & 0.009 & 0.009 & 0.239 & 0.002 & 0.222 & 0.059 & 0.131 & 0.086 & 0.877 & 0.824 \\
\hline 6 & LDL & 0.009 & 0.005 & 0.067 & 0.001 & 0.085 & 0.027 & 0.069 & 0.011 & 0.24 & 0.238 \\
\hline 7 & LDL & 0.004 & 0.005 & 0.12 & 0.001 & 0.08 & 0.017 & 0.425 & 0.004 & 0.289 & 0.3 \\
\hline 8 & LDL & 0.004 & 0.005 & 0.072 & 0.001 & 0.052 & 0.01 & 0.116 & 0.004 & 0.309 & 0.305 \\
\hline 9 & LDL & 0.01 & 0.006 & 0.106 & 0.001 & 0.011 & 0.014 & 0.152 & 0.004 & 0.256 & 0.242 \\
\hline 10 & LDL & 0.008 & 0.019 & 0.108 & 0.003 & 0.018 & 0.049 & 0.087 & 0.004 & 0.026 & 0.064 \\
\hline 11 & LDL & 0.008 & 0.004 & 0.137 & 0.001 & 0.01 & 0.023 & 0.149 & 0.004 & 0.331 & 0.342 \\
\hline 12 & 0.001 & 0.007 & 0.005 & 0.084 & 0.001 & 0.013 & 0.024 & 0.098 & 0.032 & 0.614 & 0.587 \\
\hline 13 & LDL & 0.008 & 0.005 & 0.067 & 0.001 & 0.018 & 0.023 & 0.083 & 0.004 & 0.381 & 0.377 \\
\hline 14 & 0.001 & 0.007 & 0.007 & 0.084 & 0.001 & 0.009 & 0.014 & 0.098 & 0.046 & 0.975 & 0.89 \\
\hline 15 & LDL & 0.004 & 0.005 & 0.372 & 0.003 & 0.014 & 0.022 & 0.079 & 0.008 & 0.364 & 0.343 \\
\hline 16 & LDL & 0.002 & 0.004 & 0.027 & LDL & 0.034 & 0.02 & 0.019 & 0.01 & 0.321 & 0.298 \\
\hline 17 & LDL & 0.01 & 0.005 & 0.038 & 0.002 & 0.032 & 0.021 & 0.013 & 0.004 & 0.081 & 0.085 \\
\hline 18 & LDL & 0.003 & 0.004 & 0.028 & LDL & 0.052 & 0.001 & 0.012 & 0.004 & 0.058 & 0.059 \\
\hline 19 & LDL & 0.011 & 0.005 & 0.065 & 0.001 & 0.046 & 0.01 & 0.091 & 0.004 & 0.337 & 0.322 \\
\hline 20 & LDL & 0.004 & 0.005 & 0.049 & LDL & 0.026 & 0.007 & 0.081 & 0.004 & 0.254 & 0.242 \\
\hline 21 & LDL & 0.007 & 0.005 & 0.089 & 0.001 & 0.007 & 0.01 & 0.089 & 0.004 & 0.395 & 0.393 \\
\hline 22 & LDL & 0.004 & 0.004 & 0.066 & LDL & 0.006 & 0.007 & LDL & LDL & LDL & LDL \\
\hline 23 & 0.002 & 1.211 & 0.018 & 4.916 & 0.077 & 0.785 & 0.234 & LDL & LDL & LDL & LDL \\
\hline 24 & LDL & 0.018 & 0.011 & 0.112 & 0.001 & 0.042 & 0.155 & LDL & LDL & LDL & LDL \\
\hline 25 & LDL & 0.004 & 0.002 & 0.025 & LDL & 0.002 & 0.003 & LDL & LDL & LDL & LDL \\
\hline 26 & LDL & 0.005 & 0.004 & 0.079 & LDL & 0.007 & 0.014 & LDL & LDL & LDL & LDL \\
\hline 27 & 0.001 & 1.898 & 0.032 & 7.861 & 0.128 & 1.215 & 0.018 & LDL & LDL & LDL & LDL \\
\hline 28 & 0.011 & 0.022 & 0.001 & 0.173 & 0.002 & 0.012 & 0.004 & LDL & LDL & LDL & LDL \\
\hline 29 & 0.002 & 0.003 & 0.001 & 0.034 & 0 & 0.004 & 0.007 & LDL & LDL & LDL & LDL \\
\hline 30 & LDL & 0.012 & 0.006 & 0.151 & 0.001 & 0.015 & 0.008 & LDL & LDL & LDL & LDL \\
\hline 31 & LDL & 0.013 & 0.004 & 0.068 & 0.001 & 0.009 & 0.015 & LDL & LDL & LDL & LDL \\
\hline 32 & 0.007 & 0.002 & 0.001 & 0.034 & LDL & 0.002 & 0.062 & LDL & LDL & LDL & LDL \\
\hline 33 & LDL & 0.003 & 0.005 & 0.041 & LDL & 0.006 & 0.01 & LDL & LDL & LDL & LDL \\
\hline 34 & LDL & 0.014 & 0.046 & 0.141 & 0.002 & 0.016 & 0.028 & LDL & LDL & LDL & LDL \\
\hline 35 & LDL & 0.004 & 0.005 & 0.049 & LDL & 0.01 & 0.01 & LDL & LDL & LDL & LDL \\
\hline 36 & LDL & 0.005 & 0.004 & 0.055 & 0.001 & 0.008 & 0.018 & LDL & LDL & LDL & LDL \\
\hline 37 & LDL & 0.007 & 0.009 & 0.088 & 0.001 & 0.016 & 0.016 & LDL & LDL & LDL & LDL \\
\hline 38 & LDL & 0.006 & 0.006 & 0.074 & 0.001 & 0.012 & 0.031 & LDL & LDL & LDL & LDL \\
\hline 39 & 0.001 & 0.038 & 0.007 & 0.278 & 0.005 & 0.065 & 0.089 & 0.074 & 0.087 & 0.799 & 0.778 \\
\hline 40 & 0.002 & 0.002 & 0.004 & 0.033 & 0.001 & 0.014 & 0.07 & 0.017 & 0.033 & 0.302 & 0.317 \\
\hline 41 & LDL & 0.062 & 0.032 & 0.252 & 0.003 & 0.035 & 0.041 & 0.059 & 0.008 & 0.107 & 0.142 \\
\hline 42 & LDL & 0.003 & 0.005 & 0.026 & 0.001 & 0.004 & 0.035 & 0.021 & 0.016 & 0.147 & 0.165 \\
\hline 43 & 0.001 & 0.025 & 0.007 & 0.356 & 0.003 & 0.024 & 0.084 & 0.031 & 0.021 & 0.109 & 0.136 \\
\hline 44 & LDL & 0.035 & 0.008 & 0.133 & 0.003 & 0.028 & 0.048 & 0.094 & 0.017 & 0.134 & 0.15 \\
\hline 45 & LDL & 0.012 & 0.008 & 0.094 & 0.001 & 0.01 & 0.055 & 0.024 & 0.019 & 0.121 & 0.128 \\
\hline 46 & LDL & 0.024 & 0.024 & 0.174 & 0.003 & 0.088 & 0.511 & 0.199 & 0.015 & 0.112 & 0.134 \\
\hline 47 & LDL & 0.003 & 0.005 & 0.049 & 0.002 & 0.03 & 0.086 & 0.012 & 0.021 & 0.074 & 0.086 \\
\hline 48 & LDL & 0.004 & 0.005 & 0.08 & 0.001 & 0.01 & 0.037 & 0.013 & 0.018 & 0.081 & 0.088 \\
\hline 49 & LDL & 0.003 & 0.007 & 0.038 & LDL & 0.004 & 0.05 & 0.013 & 0.017 & 0.083 & 0.092 \\
\hline 50 & LDL & 0.01 & 0.022 & 0.08 & 0.005 & 0.017 & 0.067 & 0.078 & 0.006 & 0.045 & 0.082 \\
\hline 51 & LDL & 0.036 & 0.012 & 0.181 & 0.003 & 0.03 & 0.079 & 0.095 & 0.013 & 0.092 & 0.111 \\
\hline 52 & LDL & 0.019 & 0.081 & 0.142 & 0.001 & 0.02 & 0.051 & 0.074 & 0.004 & 0.01 & 0.051 \\
\hline 53 & LDL & 0.049 & 0.02 & 0.18 & 0.018 & 0.024 & 0.033 & 0.063 & 0.004 & 0.01 & 0.05 \\
\hline 54 & LDL & 0.078 & 0.027 & 0.633 & 0.006 & 0.057 & 0.062 & 0.08 & 0.011 & 0.031 & 0.07 \\
\hline
\end{tabular}

$*$ In $\mathrm{mg} / \mathrm{kg}$.

LDL: lower detection limit, Min: minimum, Max: maximum, Avg: average, Std: standard deviation. 
TABLE I. AVERAGE CONCENTRATIONS* OF Cd, Cr, Cu, Fe, Mn, Ni, Pb, Zn, As, Se AND Al IN EDIBLE VEGETABLE OIL.

\begin{tabular}{lllllllllllll}
\hline No. & $\mathrm{Cd}$ & $\mathrm{Cr}$ & $\mathrm{Cu}$ & $\mathrm{Fe}$ & $\mathrm{Mn}$ & $\mathrm{Ni}$ & $\mathrm{Zn}$ & $\mathrm{Al}$ & $\mathrm{Pb}$ & $\mathrm{As}$ \\
\hline Min & 0.001 & 0.002 & 0.001 & 0.025 & 0.001 & 0.002 & 0.001 & 0.012 & 0.004 & 0.01 \\
Max & 0.011 & 1.898 & 0.081 & 7.861 & 0.128 & 1.215 & 0.511 & 0.425 & 0.087 & 0.975 & 0.05 \\
Avg & 0.0006 & 0.072 & 0.011 & 0.362 & 0.006 & 0.065 & 0.047 & 0.06 & 0.011 & 0.17 & 0.172 \\
Std & 0.002 & 0.307 & 0.013 & 1.256 & 0.02 & 0.196 & 0.077 & 0.073 & 0.018 & 0.229 & 0.215 \\
\hline
\end{tabular}

*In $\mathrm{mg} / \mathrm{kg}$.

LDL: lower detection limit, Min: minimum, Max: maximum, Avg: average, Std: standard deviation.

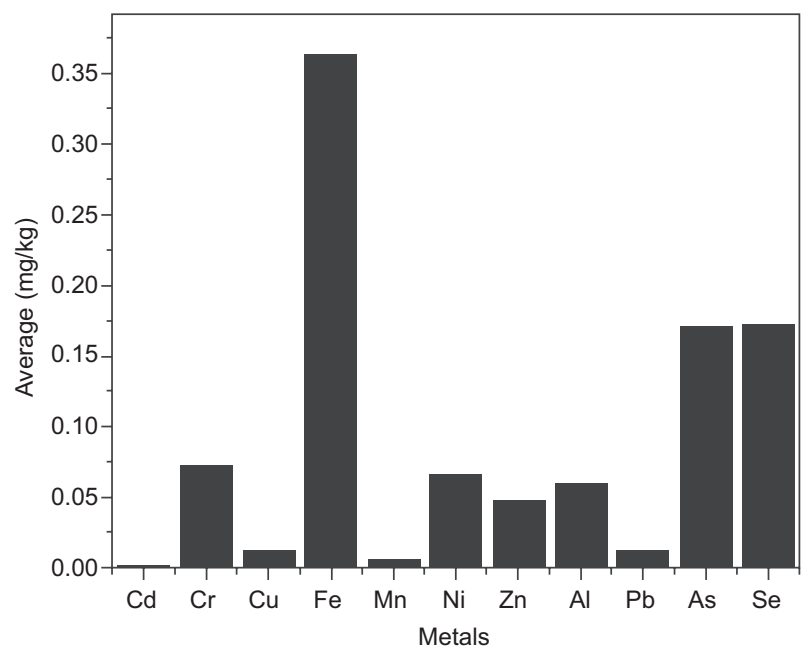

Fig. 2. $\mathrm{Cr}, \mathrm{Cu}, \mathrm{Fe}, \mathrm{Mn}, \mathrm{Ni}, \mathrm{Zn}, \mathrm{Al}, \mathrm{Pb}, \mathrm{As}, \mathrm{As}$, and $\mathrm{Se}$ concentrations (in $\mathrm{mg} / \mathrm{kg}$ ) and statistical summary of edible vegetable oil samples.

\section{Zinc}

Zn concentrations varied from 0.001 to $0.511 \mathrm{mg} / \mathrm{kg}$ ith an average value of $0.047 \mathrm{mg} / \mathrm{kg}$. From the obtained results, the $\mathrm{Zn}$ concentration range was higher than the control samples $(0.002 \mathrm{mg} / \mathrm{kg})$, however $\mathrm{Zn}$ concentrations in this investigation were lower than in similar data reported by numerous researchers (Garrido et al. 1994, Mendil et al. 2009). The Zn average daily intake $(0.017 \mathrm{mg} / \mathrm{kg})$ was found to be lower than the maximum legal limit set by WHO (1995) (60 mg mg/kg). Zn has an essential function in carbohydrate and cholesterol metabolism.

\section{Manganese}

Mn is essential in many biological processes such as immunity functions, blood sugar regulation and bone growth, as well as being a cell antioxidant (Pfalzer and Bowman 2017). This element was detected in 43 of the 54 samples within a range of $0.001-0.128 \mathrm{mg} / \mathrm{kg}$ with an average value of $0.002 \mathrm{mg} / \mathrm{kg}$. In comparison, manganese average values in the investigated samples were lower than in a similar studies (Garrido et al. 1994, Cindiric et al. 2007, Mendil et al. 2009, Llorent et al. 2011). Manganese average daily intake $0.006 \mathrm{mg} / \mathrm{kg}$ was found to be lower than the maximum limit set by WHO (1995) $(2.5-5 \mathrm{mg} / \mathrm{kg})$.

\section{Chromium}

$\mathrm{Cr}$ is important in the metabolism of glucose, as reported by Yagi et al. (2013). The toxic effects of $\mathrm{Cr}^{+3}$ intake include skin rash, nose irritation, bleeding, upset stomach, kidney and liver damage. $\mathrm{Cr}$ concentrations varied from 0.002 to $1.898 \mathrm{mg} / \mathrm{kg}$ with an average value of $0.026 \mathrm{mg} / \mathrm{kg}$. The concentration of control samples was $0.003 \mathrm{mg} / \mathrm{kg}$.

\section{Iron}

$\mathrm{Fe}$ was found within the range of $0.025-7.861$ $\mathrm{mg} / \mathrm{kg}$ with an average value of $0.362 \mathrm{mg} / \mathrm{kg}$. The average daily intake of this element $(0.129 \mathrm{mg} / \mathrm{kg})$ was found to be lower than the maximum allowable limit (11-18 mg/kg) (Institute of Medicine 2001). The concentrations of control samples was $0.027 \mathrm{mg} / \mathrm{kg}$. It is well known that $\mathrm{Fe}$ is indispensable for human beings and animals and is an essential component of hemoglobin. It facilitates the oxidation of carbohydrates, proteins and fats to control body weight, which is an extremely important factor in diabetes; furthermore, an Fe deficiency can induce anemia. The recommended daily allowance (RDA) for Fe is 11 and $18 \mathrm{mg}$ /day for children and adults, respectively (Schüman et al. 2007).

\section{Selenium}

Se was present in a range of $0.05-0.89 \mathrm{mg} / \mathrm{kg}$ with an average of $0.172 \mathrm{mg} / \mathrm{kg}$, while the control sample concentration was $0.004 \mathrm{mg} / \mathrm{kg}$. The average daily intake of Se (0.025) $\mathrm{mg}$ was found to be lower than the maximum allowable concentration limit 0.55 $\mathrm{mg} / \mathrm{kg}$ (Schüman et al. 2007) (Institute of Medicine 2001). Se is an essential element for human nutrition and plays an important role in the protection of the body from cancer and heart disease (Wan et al. 2020). 
Its RDA is $0.55 \mathrm{mg} /$ day (Institute of Medicine 2001, Schüman et al. 2007).

\section{Cadmium}

Ca was detected in 14 of the 54 samples. Concentrations of this element in the samples were found to be in the range of $0.001-0.011 \mathrm{mg} / \mathrm{kg}$, with an average value of $0.0006 \mathrm{mg} / \mathrm{kg}$. The concentration in control samples was $0.001 \mathrm{mg} / \mathrm{kg}$. All the investigated samples showed lower $\mathrm{Ca}$ levels than the legal limits recommended by FAO-WHO $(0.5 \mathrm{mg} / \mathrm{kg})$ (Codex S 2011). Ca is an extremely toxic metal found naturally in soil, but also spread in the environment due to human activity. Overexposure to Ca can lead to lung, liver, skeletal, and renal problems, as well as cancer (Djordjevic et al. 2019).

\section{Arsenic}

The As content in samples were in the range of $0.01-0.975 \mathrm{mg} / \mathrm{kg}$ with an average value of $0.17 \mathrm{mg} /$ $\mathrm{kg}$. The obtained values fell far below the action level recommended by FAO/WHO of $0.5 \mathrm{mg} / \mathrm{kg}$ (Codex S 2011). The control sample concentration was $0.01 \mathrm{mg} /$ $\mathrm{kg}$. As is a naturally occurring element that can be toxic to humans, animals and plants; however, its toxicity varies depending on its presentation form (Kim et al. 2018).

\section{Aluminum}

Al concentrations were in the range of 0.012 $0.425 \mathrm{mg} / \mathrm{kg}$, with an average value of $0.06 \mathrm{mg} / \mathrm{kg}$. The control sample concentration was $0.001 \mathrm{mg} / \mathrm{kg}$. The toxicity of Al in humans is mainly related to neurotoxicity and the development of neurodegenerative diseases (Verstraeten et al. 2008). It was difficult to compare our obtained results for $\mathrm{Al}$ with worldwide concentrations due to the scarcity of data. The FAOWHO tolerable weekly intake value for $\mathrm{Al}$ is $1 \mathrm{mg}$ / $\mathrm{kg}$ body weight/week (Stahl et al. 2011).

\section{Lead}

$\mathrm{Pb}$ was detected in 16 of the 37 samples with concentrations ranging from 0.004 to $0.087 \mathrm{mg} /$ $\mathrm{kg}$ and an average of $0.011 \mathrm{mg} / \mathrm{kg}$. The $\mathrm{Pb}$ control sample concentration was $0.01 \mathrm{mg} / \mathrm{kg}$. From the obtained results, the $\mathrm{Pb}$ concentration range was lower than in similar data reported in Turkey. The $\mathrm{Pb}$ concentration in the current study fell within the recommended limits set by FAO/WHO $(0.1 \mathrm{mg} / \mathrm{kg})$ (Codex S 2011). Lead is a naturally occurring element and is a widespread industrial metal. $\mathrm{Pb}$ has severe health effects even at relatively low levels. It is able to cross the placenta and damage the developing fetal nervous systems (Łukomska et al. 2017). Pb causes both acute and chronic poisoning; it has adverse effects on the kidneys, liver, heart and both the vascular and immune systems.

\section{Correlation coefficient test}

Correlations support the interpretation of meaningful measurements. This approach also helps to identify common factors, inducing the observation of elemental relationships. A high value of the coefficient reveals a high linear correlation between the contents of two elements. Table II shows the Spearman correlation coefficient (r) between the elements in oil samples. It was found that the correlation matrix of investigated oil samples showed a cluster of high positive correlation between the variables $\mathrm{Cr}$ and $\mathrm{Fe}$ (0.998), $\mathrm{Cr}$ and $\mathrm{Mn}$ (0.994), $\mathrm{Cr}$ and $\mathrm{Ni}$ (0.985), $\mathrm{Fe}$ and Mn (0.994), Fe and Ni (0.985), Mn and Ni (0.978), As and Se (0.997). This indicates that there

TABLE II. PEARSON CORRELATION COEFFICIENTS FOR Mn, Fe, Cu, Cr, Zn, Ni, Al, Pb, As, Se AND Al IN EDIBLE VEGETABLE OIL SAMPLES.

\begin{tabular}{|c|c|c|c|c|c|c|c|c|c|c|c|}
\hline & $\mathrm{Cd}$ & $\mathrm{Cr}$ & $\mathrm{Cu}$ & $\mathrm{Fe}$ & $\mathrm{Mn}$ & $\mathrm{Ni}$ & $\mathrm{Zn}$ & $\mathrm{Al}$ & $\mathrm{Pb}$ & As & $\mathrm{Se}$ \\
\hline $\mathrm{Cd}$ & 1.000 & & & & & & & & & & \\
\hline $\mathrm{Cr}$ & 0.085 & 1.000 & & & & & & & & & \\
\hline $\mathrm{Cu}$ & -0.150 & 0.256 & 1.000 & & & & & & & & \\
\hline $\mathrm{Fe}$ & 0.087 & 0.998 & 0.260 & 1.000 & & & & & & & \\
\hline Mn & 0.076 & 0.994 & 0.269 & 0.992 & 1.000 & & & & & & \\
\hline $\mathrm{Ni}$ & 0.070 & 0.985 & 0.243 & 0.985 & 0.978 & 1.000 & & & & & \\
\hline $\mathrm{Zn}$ & -0.007 & 0.154 & 0.228 & 0.154 & 0.152 & 0.191 & 1.000 & & & & \\
\hline $\mathrm{Al}$ & -0.136 & -0.145 & 0.008 & -0.125 & -0.137 & -0.080 & 0.136 & 1.000 & & & \\
\hline $\mathrm{Pb}$ & 0.008 & -0.106 & -0.072 & -0.090 & -0.094 & -0.011 & 0.145 & 0.143 & 1.000 & & \\
\hline As & -0.042 & -0.149 & -0.208 & -0.133 & -0.147 & -0.066 & -0.062 & 0.433 & 0.768 & 1.000 & \\
\hline $\mathrm{Se}$ & -0.056 & -0.159 & -0.180 & -0.142 & -0.154 & -0.076 & -0.044 & 0.454 & 0.778 & 0.997 & 1.000 \\
\hline
\end{tabular}

Note: values in bold characters represent a $>0.5$ correlation. 
is a strong relationship between these elements. On the other hand, moderate positive correlations were noted between $\mathrm{Pb}$ and $\mathrm{As}(0.768)$, and between $\mathrm{PB}$ and Se (0.778). Overall, the correlation behavior of elements in the studied samples remained noticeably diverse, which may be attributed to the disproportions of the origin of samples.

\section{CONCLUSIONS}

Based on the obtained results the following conclusions may be drawn:

- No contamination was observed in the samples analyzed.

- There are no significant differences in the concentrations of studied oils because all of them were found to be lower than the maximum allowable limits set by FAO and WHO.

- Significant correlations were observed between $\mathrm{Cr}$ and $\mathrm{Fe}$ (0.998), $\mathrm{Cr}$ and $\mathrm{Mn}$ (0.994), $\mathrm{Cr}$ and $\mathrm{Ni}$ (0.985), Fe and Mn (0.994), Fe and Ni (0.985), $\mathrm{Mn}$ and Ni (0.978), and As and Se (0.997)

\section{REFERENCES}

Al-Rajhi M. A. (2014). Determination the concentration of some metals in imported canned food and chicken stock. Am. J. Environ. Sci. 10 (3), 283-288. https://doi. org/10.3844/ajessp.2014.283.288†

Ameen N., Amjad M., Murtaza B., Abbas G., Shahid M., Imran M., Naeem M.A. and Niazi N.K. (2019). Biogeochemical behavior of nickel under different abiotic stresses: Toxicity and detoxification mechanisms in plants. Environ. Sci. Pollut. Res. 26 (11), 10496-10514. $\uparrow$ https://doi.org/10.1007/s11356-019-04540-4

Bakkali K., Martos N.R., Souhail B and Ballesteros E. (2012). Determination of heavy metal content in vegetables and oils from Spain and Morocco by inductively coupled plasma mass spectrometry. Anal. Lett. 45 (8), 907-919.] https://doi.org/10.1080/00032 719.2012.655658

Barreto I.S., Andrade S.I., Cunha F.A., Lima M.B., Araujo M.C.U and Almeida L.F. (2018). A robotic magnetic nanoparticle solid phase extraction system coupled to flow-batch analyzer and GFAAS for determination of trace cadmium in edible oils without external pretreatment. Talanta 178, 384-391. https://doi.org/10.1016/j. talanta.2017.09.063

Buldini P.L., Ferri D. and Sharma J.L. (1997). Determination of some inorganic species in edible vegetable oils and fats by ion chromatography. J. Chromatogr. A 789 (1-2), 549-555. https://doi.org/10.1016/S00219673(97)00822-4

Cindiric I.J., Zeiner M. and Steffan I. (2007). Trace elemental characterization of edible oils by ICP-AES and GFAAS. Microchem. J. 85, 136-139. https://doi. org/10.1016/j.microc.2006.04.011

Codex S (2011). Codex Standard for Named Vegetable Oils (Codex Stan 210-1999). Food and Agriculture Organization of the United Nations and World Health Organization, Rome, Italy.

Djordjevic V.R., Wallace D.R., Schweitzer A., Boricic N., Knezevic D., Matic S., Grubor N., Kerkez M., Radenkovic D., Bulat Z. and Antonijevic B. (2019). Environmental cadmium exposure and pancreatic cancer: Evidence from case control, animal and in vitro studies. Environ. Int. 128, 353-361. https://doi. org/10.1016/j.envint.2019.04.048

Dugo G., La Pera L., La Torre G.L. and Giuffrida D. (2004). Determination of Cd (II), Cu (II), Pb (II), and $\mathrm{Zn}$ (II) content in commercial vegetable oils using derivative potentiometric stripping analysis. Food Chem. 87 (4), 639-645. https://doi.org/10.1016/j. foodchem.2003.12.035

FAO-WHO (1999). Expert Committee on Food Additives Fifty-third Meeting. Summary and conclusions. Proceedings. Food and Agriculture Organization of the United Nations and World Health Organization, Rome, Italy [online]. http://www.fao.org/tempref/codex/Meetings/CCFAC/CCFAC32/JECFA_53.pdf. 3/8/2020

Garrido M.D., Frías I., Díaz C. and Hardisson A. (1994). Concentrations of metals in vegetable edible oils. Food. Chem. 50, 237-243. https://doi.org/10.1016/03088146(94)90127-9

Institute of Medicine. 2001. Dietary reference intakes for vitamin A, vitamin K, arsenic, boron, chromium, copper, iodine, iron, manganese, molybdenum, nickel, silicon, vanadium, and zinc. The National Academies Press, Washington, DC, 773 pp. https://doi. org/10.17226/10026.

Jamali M.K., Kazi T.G., Arain M.B., Afridi H.I., Jalbani N., Sarfraz R.A. and Baig J.A. (2008). A multivariate study: Variation in uptake of trace and toxic elements by various varieties of Sorghum bicolor L. J. Hazard. Mater. 158 (2-3), 644-651. https://doi.org/10.1016/j. jhazmat.2008.02.007

Karasakal A. (2020). Determination of trace and major elements in vegan milk and oils by ICP-OES after microwave digestion. Biol. Trace. Elem. Res. 4, 223-228. https://doi.org/10.1007/s12011-019-02024-7

Karimi M., Dadfarnia S., Shabani A.M.H., Tamaddon F. and Azadi D. (2015). Deep eutectic liquid organic salt as a new solvent for liquid-phase micro extraction and 
its application in ligand less extraction and preconcentraion of lead and cadmium in edible oils. Talanta 144, 648-654.'https://doi.org/10.1016/j.talanta.2015.07.021

Kim H.T., Loftus J.P., Mann S. and Wakshlag J.J. (2018). Evaluation of arsenic, cadmium, lead and mercury contamination in over-the-counter available dry dog foods with different animal ingredients (red meat, poultry, and fish). Front. Vet. Sci. 5, ID 264. https:// doi.org/10.3389/fvets.2018.00264

Llorent-Martínez E.J., Ortega-Barrales P., Fernández-de Córdova M.L. and Ruiz-Medina. A. (2011). Analysis of the legislated metals in different categories of olive and olive-pomace oils. Food Control 22 (2), 221-225. Thttps://doi.org/10.1016/j.foodcont.2010.07.002

Łukomska A., Baranowska-Bosiacka I., Budkowska M., Pilutin A., Tarnowski M., Dec K., Dołęgowska B., Metryka E., Chlubek D. and Gutowska I. (2017). The effect of low levels of lead $(\mathrm{Pb})$ in the blood on levels of sphingosine-1-phosphate (S1P) and expression of S1P receptor 1 in the brain of the rat in the perinatal period. Chemosphere 166, 221-229.'https://doi.org/10.1016/j. chemosphere.2016.09.067

Manjusha R., Shekhar R. and Kumar S.J. (2019). Ultrasound-assisted extraction of $\mathrm{Pb}, \mathrm{Cd}, \mathrm{Cr}, \mathrm{Mn}, \mathrm{Fe}$, $\mathrm{Cu}, \mathrm{Zn}$ from edible oils with tetra methyl ammonium hydroxide and EDTA followed by determination using graphite furnace atomic absorption spectrometer. Food Chem. 294, 384-389. 'https://doi.org/10.1016/j. foodchem.2019.04.104

Mendil D., Uluözlü Ö.D., Tüzen M. and Soylak M. (2009). Investigation of the levels of some element in edible oil samples produced in Turkey by atomic absorption spectrometry. J. Hazard. Mater. 165 (1-3), 724-728. Thttps://doi.org/10.1016/j.jhazmat.2008.10.046

Pfalzer A.C. and Bowman A.B. (2017). Relationships between essential manganese biology and manganese toxicity in neurological disease. Curr. Environ. Health Rep. 4, 223-228. https://doi.org/10.1007/s40572-017-0136-1

Rajeshkumar S., Liu Y., Ma J., Duan H.Y. and Li X. (2017). Effects of exposure to multiple heavy metals on biochemical and histopathological alterations in common carp, Cyprinus carpio L. Fish Shellfish Immun. 70, 461-472.'thttps://doi.org/10.1016/j.fsi.2017.08.013

Sanches-Filho P.J., Caldas J.S., da Rosa N.N. and Pereira F.O.P. (2017). Toxicity test and $\mathrm{Cd}, \mathrm{Cr}, \mathrm{Pb}$ and $\mathrm{Zn}$ bioccumulation in Phalloceros caudimaculatus. Egypt. J. Basic Appl. Sci. 4 (3), 206-211. https://doi. org/10.1016/j.ejbas.2017.06.001
Savio M., Ortiz M.S., Almeida C.A., Olsina R.A., Martínez L.D. and Gil R.A. (2014). Multielemental analysis in vegetable edible oils by inductively coupled plasma mass spectrometry after solubilisation with tetra methyl ammonium hydroxide. Food. Chem. 159, 433-438. "https://doi.org/10.1016/j.foodchem.2014.03.041

Schümann K., Ettle T., Szegner B., Elsenhans B. and Solomons N.W. (2007). On risks and benefits of iron supplementation recommendations for iron intake revisited. J. Trace Elem. Med. Biol. 21 (3), 147-168. https://doi.org/10.1016/j.jtemb.2007.06.002

Sobhan Ardakani S. (2016). Health risk assessment of As and $\mathrm{Zn}$ in canola and soybean oils consumed in Kermanshah, Iran. J. Adv. Environ. Health Res. 4 (2), 62-67.'Thttps://doi.org/10.22102/jaehr.2016.40222

Stahl T., Taschan H. and Brunn H. (2011). Aluminum content of selected foods and food products. Environ. Sci. Eur. 23 (1), 37. https://doi.org/10.1186/21904715-23-37

Verstraeten S.V., Aimo L. and Oteiza P.I. (2008). Aluminum and lead: Molecular mechanisms of brain toxicity. Arch. Toxicol. 82 (11), 789-802.) https://doi. org/10.1007/s00204-008-0345-3

Wan F., Zhong G., Ning Z., Liao J., Yu W., Wang C., Han Q., Li Y., Pan J., Tang Z. and Huang R. (2020). Long-term exposure to copper induces autophagy and apoptosis through oxidative stress in rat kidneys. Ecotoxicol. Environ. Saf. 190, 110-158. Thttps://doi. org/10.1016/j.ecoenv.2019.110158

WHO (1995). Global Environment Monitoring System: Food contamination monitoring and assessment programme: Compilation of analytical quality assurance study reports, 1994. World Health Organization, Food Safety Team and Global Environment Monitoring System, Food Contamination Monitoring and Assesssment Programme [online]. https://apps.who.int/iris/ handle/10665/58537 3/8/2020

Yagi S., Rahman A.E.A., Elhassan G.O. and Mohammed A.M. (2013). Elemental analysis of ten Sudanese medicinal plants using X-ray fluorescence. J. Appl. Ind. Sci. 1 (1), 49-53.9

Zeiner M., Steffan I., Cindiric I.J. (2005). Determination of trace elements in olive ICP-AES and ETA-AAS: A pilot study on the geographical characterization. Microchem. J. 81, 171-176. https://doi.org/10.1016/j. microc.2004.12.002 